\title{
The Exploration of Competitive State in Electricity Retail Company under the Background of New Power Market Reformation
}

\author{
Cai-qing ZHANG ${ }^{1, a,{ }^{*}}$ and Jun-jie YANG $^{2, b}$ \\ ${ }^{1,2}$ Department of Economic Management, North China Electric Power University, \\ Baoding city, Hebei Province, China \\ ahdzhangcaiqing@126.com, 'Yangjunjie_1994@163.com
}

Keywords: New power market reformation, Electricity Retail Company, Competitiveness analysis, Porter's Five Forces Model.

\begin{abstract}
With the reformation of power sale side moving forward constantly, an increasing number of electricity retail companies are involved in the competition of selling market, which is contributed by the release of retail side. Aimed at this background, the present paper explored the competition situation of the whole market, based on the Potter 's five force model from five aspects: the current rivals, the threats of entry, the threats of substitutes, the bargaining power of suppliers and the bargaining power of buyers. Finally, the relevant competitive strategies and suggestions were put forward for the current electricity retail companies.
\end{abstract}

\section{Introduction}

A government document named Relative Policies on Deepening the Reform of Power Industry was issued by the State Council on March 25th, 2015, which published reform policies from the following aspects: pricing mechanism, promotion of renewable energy generation, power system planning mechanism and repositioning of grid enterprises. On March 1, 2016, the founding of the power exchange center in Beijing and Guangzhou marks the entirely development of China's new round of electricity market reform. The new policies for the retail side reform has been released on October 8 by the National Development and Reform Commission, mainly explaining the basic problems in the process of this reform, such as power selling subject, market regulation and business scope of distribution network. Currently, the main selling subjects in power selling market can be divided into the following categories:(1) power network enterprise; (2) large-scale power generation company; (3) construction corporation associated with power grid and energy service company closed to users; (4) power selling subject established in large industrial park; (5) electricity selling body organized by social capital; (6) assurance institutions of electricity-sale service. However, with the increasing establishment of electricity Retail Company, the competition of power sale market is becoming increasingly fierce. To this case, this paper will analyze the current competitive situation of electricity sales side using Porter's Five Forces Model. Then the corresponding strategic suggestions are put forward, which provide electricity Retail Company with appropriate reference to develop related businesses and construct competitive strategies. 


\section{Literature Review}

At present, the academic circle has conducted various researches concerning the new round of electricity retail reform. The business mode of electricity Retail Company has been studied by several researchers. Hao SUN and Feng-dong SUN (2016) analyzed the business environment and market positioning of electricity Retail Company established by power Generation Corporation, giving some suggestions from the perspective of "6PS" organization, such as forming perfect product portfolio and mapping out the price system scientifically [1]. The operation model and critical business of market-oriented power selling body have been explored by Yin-bin DUAN(2016), which based on the connotation of competitive market and the theory of business model elements, then the top-level business planning under the coming competitive situation was proposed, connecting with the development trend of domestic electricity market[2]. Furthermore, relevant studies on the competition strategy of electricity Retail Company have been conducted by some scholars. Jie LIU (2016) indicated that, following the direction of this reform, the approach of environment-protecting and intellectualized development should be adopted by power Retail Company [3]. Through exploring the core competence and superiority of power retail enterprise with different forms, it has been suggested by Yu LIAO (2016) that the possibility of opening, cross-border thinking and diversified operation is the core competitive power belonging to electricity Retail Company [4].

In conclusion, whilst there are abundant researches on business mode and competition strategy of power Retail Corporation, only a few studies have been conducted to explore the whole electricity retail industry's competitive state. Most scholars focused on the analysis on various types of companies, while few conducted in-depth analysis towards entire industry from a more macroscopic level with comprehensive and systematic investigation. In the future, with the constant introduction of supplementary measures for the retail side reform, more explorations are needed for further analysis and complementary.

\section{Analysis on the Competitive Status of Electricity Retail Industry}

Porter's competitive theory argues that there are five competitive forces in an industry, including the current rivals, the threats of entry, and the threats of substitutes, the bargaining power of suppliers and the bargaining power of buyers [5].

\section{The Exploration of Present Competitors}

Currently,3512 electricity retail enterprises were established across the country[6], and the quantity and distribution are illustrated in Figure 1.It is not difficult to find that, the competition of power retail market will become increasingly fierce, especially in the regions of southwestern, South and North China. 


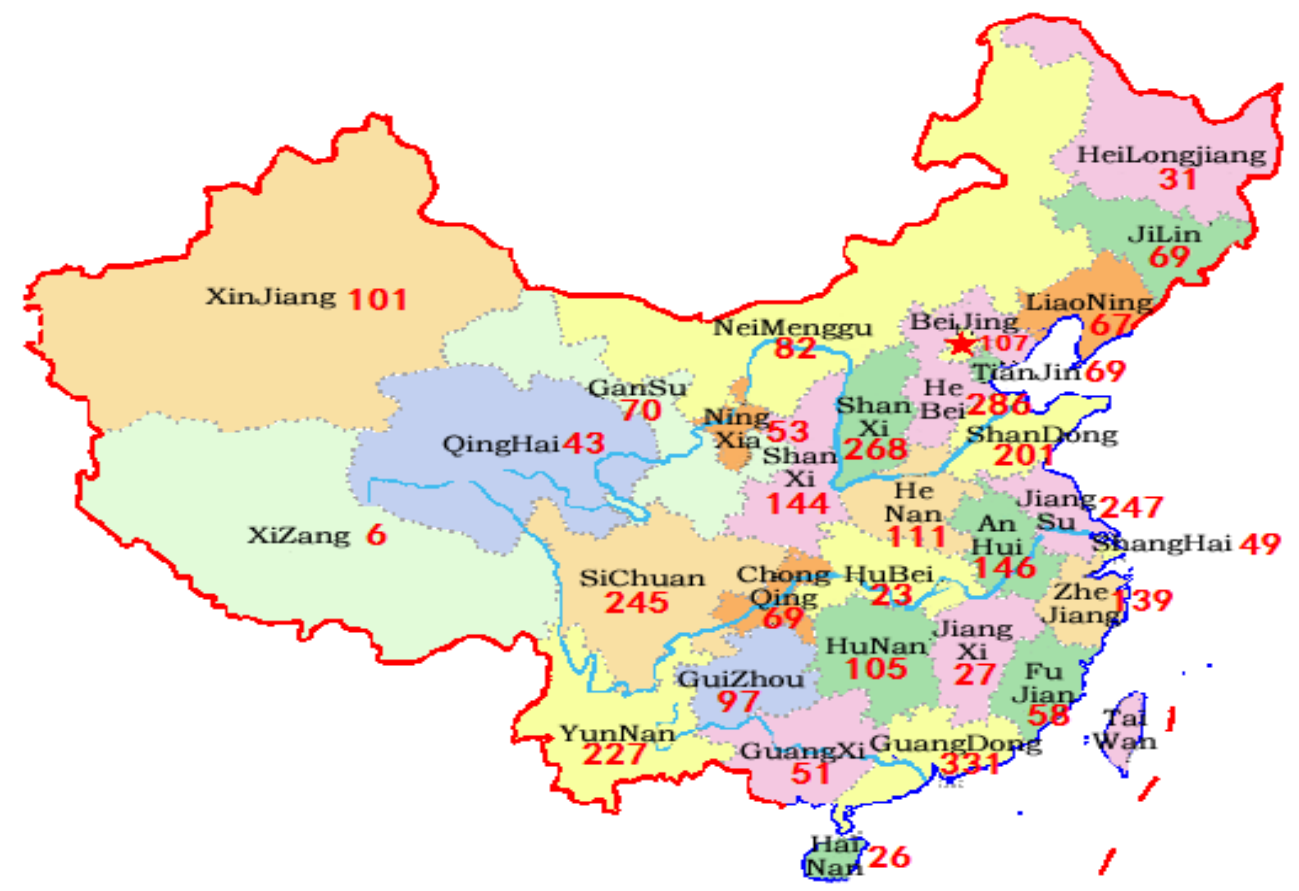

Figure 1. The quantity and distribution of power retail company

In the current electricity market, the competitive strengths and weakness are investigated as Table 1. It should be noted that the assurance institutions of electricity-sale service always undertake responsibility in providing universal service without taking profit making as purpose, and thus beyond the scope of this article.

Table 1. the Analysis of competitive strengths and weakness

\begin{tabular}{|c|c|c|}
\hline $\begin{array}{c}\text { Categories of Power } \\
\text { Selling Body }\end{array}$ & Strengths & Weaknesses \\
\hline Grid Companies & $\begin{array}{l}\text { (1)rich services experience and consumer } \\
\text { inertia } \\
\text { (2)broad coverage of distribution network }\end{array}$ & $\begin{array}{l}\text { (1)weak competition } \\
\text { consciousness } \\
\text { (2)poor flexibility }\end{array}$ \\
\hline $\begin{array}{l}\text { Power Generation } \\
\text { Enterprise }\end{array}$ & $\begin{array}{l}\text { (1)owning generating assets } \\
\text { (2)the ability of self-marketing and } \\
\text { combining production and sale }\end{array}$ & $\begin{array}{l}\text { (1)lack of relevant } \\
\text { experience } \\
\text { (2)single type of product }\end{array}$ \\
\hline $\begin{array}{l}\text { Construction } \\
\text { Company } \\
\text { And Energy } \\
\text { Management } \\
\text { Corporation }\end{array}$ & $\begin{array}{l}\text { (1)certain experience in their former } \\
\text { sectors } \\
\text { (2)more close to consumers }\end{array}$ & $\begin{array}{l}\text { (1)short on electricity } \\
\text { allocation and sales assets } \\
\text { (2)lacking famous brands }\end{array}$ \\
\hline Industrial Park & $\begin{array}{l}\text { (1)stable target clients and monopoly } \\
\text { advantage } \\
\text { (2)developing a better understanding of } \\
\text { customer demand }\end{array}$ & $\begin{array}{l}\text { (1)limited market of the } \\
\text { park } \\
\text { (2)difficult in expansion }\end{array}$ \\
\hline Social Capital & $\begin{array}{l}\text { (1)more innovative and flexible } \\
\text { (2)the ability to introducing advanced } \\
\text { ideas and methods from other industries }\end{array}$ & $\begin{array}{l}\text { (1)lack of experience on } \\
\text { electrical power } \\
\text { (2)weaker in overall } \\
\text { strength }\end{array}$ \\
\hline
\end{tabular}

\section{The Threats of Entry Potential Competitor}

The access conditions and procedures as well as the quit channels of power Retail Company have been regulated on October 11, 2016, which specifying that the total assets of electricity retail enterprise will not be lower than 20 million RMB. The high entry and exit threshold bring specified pressure on potential competitors. 
At present, the latent rivals of power Retail Company include the following kinds:

(1) Other energy enterprise. Other energy company could participate in the competition of retail side, resorting to the possession of other energy resources as their capital and backing, and develop towards integrated energy service provider.

(2) Foreign company concerned with electricity. Those foreign companies have already accumulated some advanced technology and relevant experience based on the previous operation, and has been provided with the ability to better accommodate the environment and change of reform.

(3) Internet Company. The electricity retail business founded by Internet firm has the benefit of powerful Internet technology and data analysis capability, which provides them with an effective approach to make full use of the development of Energy Internet and integrate smart grid with intelligent mobile terminal.

(4) Public service enterprise. These companies, owning the distributed energy or supplying heat and gas, have the access to a vast customer base, which are more effective in providing value-added services such as energy efficiency management.

\section{The Threat of Substitutes}

In the energy sector, electricity has long been a substitute for oil, gas, coal and solar energy. Because of the fact that oil and gas belong to non-renewable energy and their characteristics like high cost and serious pollution, the implement of electric power alteration is energetically encouraged by the country. Meanwhile, solar energy also gradually began to develop as another kind of clean energy but it lack of competitive power results from the limitation of weather and geographic conditions.

Electric power and natural gas both are clean, efficient, low-cost, and high-quality energy. Both of them have competition in some domain of high energy consumption, especially after the implementation of West-to-East Gas Transportation Project. Compared with electric power, the natural gas possesses certain economic advantages and better energy efficiency without high pollution emissions, which contributed to the popularization of gas water heater and home-use cooker. On the whole, considering the high switching cost of energy device, natural gas will be the major alternative to electric power within a certain period of time.

\section{The Bargaining Power of Buyers}

Explicit in this is that the buyers in power retail market are electricity customers. Prior to this round of reform, there is only one seller, namely power Grid Corporation, faced with numerous consumers. Under such circumstances, Grid Company was in the monopoly situation of selling party. Although power price has been regulated by Government, arguably, the bargaining power of buyers is extremely limited.

After the opening of power retail market, the advent of numerous electricity retail companies will press the trigger of competition on a grand scale. Consequently, the concentration degree of supplier will gradually decrease while the selectivity of consumer will increase conversely, which means, to seize more market percentages, more effort need to be put into price, quality and service. Therefore, there will demonstrate some improvements on electricity customers' bargaining capability to some degrees, as well as their discourse power.

\section{The Bargaining Power of Suppliers}

The suppliers in power retail market are power generation business. After the implementation of previous reform in 2002, power plants were thoroughly separated from electric network in the aspect of asset. As equally competent market players, 
both of them need to conduct transaction following the rules of the market.

Nowadays, the new round of retail side reform makes it possible for power generation enterprise to engage in the competition of electric selling market. Unlike in the past the power plants only allowed to trade with grid enterprise, now they could conduct a transaction with electricity retail company either, which will decrease their dependence on grid firm. Meanwhile, the forward integration strategy is available for Generation Company to sell electricity for large power end-use. At the same time, generation firms will move from the position of supplier to that of competitor, and its bargaining power will be improved accordingly.

\section{The Competitive Strategy of Power Retail Company}

\section{Cost-leading Strategy}

Cost-leading strategy indicates that by strengthening internal cost control, company's products cost maintains a leading level in the same industry, with low cost being regarded as the main competition means.

The main cost of electricity retail enterprise is electricity purchasing cost, which stands for $80 \%$ of total costs. For power Retail Company with generation property, the purchasing costs are lower than others and the provision are more stable, which makes it possible to have certain advantages in reducing cost and implementing the strategy. On the other hand, in terms of companies without generating assets, they need to choose suitable power resources and electricity prices in market, and seek cooperation with them. Meanwhile, those companies could make full use of distributed energy and actively collect the margin of that, which not only saves the electricity costs of users but also reduces purchasing cost and increase extra income.

\section{Differentiation Strategy}

Differentiation strategy refers to that the enterprise, according to the market demand, should focus on a field based on their resources and ability, to seek the development of the enterprise.

Firstly, they could focus on costumers' characteristics to help user choose personalized service package and provide customized service. Meanwhile, through energy saving management equipment such as smart electricity meter, their electronic behaviors can be analyzed, contributing to providing related energy saving advice or equipment. In Addition, as a proxy for the client of a certain area, retail enterprise can gather resource of demand response and participate in fierce market competition, namely, demand response services. For example, in the United States, electricity retail companies have been conducting cooperation with internet or information and communication technology enterprises. On the one hand, based on the Cloud Platform, they realized the analysis, prediction and monitoring of the big data gathered by intelligent ammeter, which elevated the precision of consumer's demand response to price signals and load curtailment [7]. On the other hand, power demand side management has been conducting based on energy intelligence center [8].

\section{Focusing Strategy}

Focusing strategy is defined that on the basis of specifically analysis external and internal conditions, enterprises choose one typical target market to provide products and services, which aims at build up competitive edge and marketing status.

In the surroundings of competition, electricity selling market always is conceived as a big piece of cake, which can be divided into several parts. It's impossible for any 
company to control the whole market. Especially for the power retail company with limited capital and small scale, without the ability to enter bigger market, the most appropriate strategy is that, aimed at its own advantages, the firm selects a segment market match with its capacity and resources, analyzes characteristics and demand there in depth, and make available related products and services pertinently. Then, while providing services to the market, the competitive advantage is acquired and low cost or differentiation is achieved. Once the enterprise has deeply rooted in its market segment, the strong defensive positions and market status is established.

\section{Conclusions}

With the constantly improving of reform mechanism and policy and the increasing establishment of electricity Retail Company, the competition will become more intense in the future. This paper explored the competition situation of the whole market based on the Potter 's five force model. Then, the relevant competitive strategy and suggestions are put forward for the current electricity retail companies, which hope to provide related reference in the fierce competition of electrical markets. Meanwhile, it is necessary for electricity Retail Company to keep exploring and practicing, summarize experiences and promote stable development of the retail side reform.

\section{References}

[1] Hao SUN, China Power Enterprise Management. 11(2016) 46-48. (In Chinese)

[2] Yin-bin DUAN, Power Demand Side Management.3 (2016) 41-45. (In Chinese)

[3] Jie LIU, Operation Management.15 (2016) 125-126. (In Chinese)

[4] Yu LIAO, China Power Enterprise Management.7 (2016) 28-30. (In Chinese)

[5] Michael E. Porter. Competitive Strategy: Techniques for Analyzing Industries and Competitors, Free Press, New York, 2004.

[6] Information on http://shoudian.bjx.com.cn/news/20161111/788280-2.shtml

[7] Mahdi Behrangrad, Renewable and Sustainable Energy Reviews. 47(2015) 270-283.

[8] Aras Sheikhi, Mohammad Rayati, Shahab Bahrami, et al, International Journal of Electrical Power \& Energy Systems, 64 (2015) 1007-1016. 